\title{
Publisher's Erratum to: Metamaterial-based graphene thermal emitter
}

\author{
Cheng Shi, Nathan H. Mahlmeister, Isaac J. Luxmoore, and Geoffrey R. Nash ${ }^{2}(\varangle)$ \\ College of Engineering, Mathematics and Physical Sciences, University of Exeter, Exeter, EX4 4QF, UK \\ C The author(s) 2018. This article is published with open access at link.Springer.com
}

\section{Erratum to}

Nano Research

https://doi.org/10.1007/s12274-017-1922-7

The article Metamaterial-based graphene thermal emitter, written by Cheng Shi, Nathan H. Mahlmeister, Isaac J. Luxmoore, and Geoffrey R. Nash, was originally published electronically on the publisher's internet portal (currently SpringerLink) on December 6th 2017 without open access. With the author(s)' decision to opt for Open Choice the copyright of the article changed in February 2018 to (c) The Author(s) 2018 and the article is forthwith distributed under the terms of the Creative Commons Attribution 4.0 International License (http://creativecommons.org/licenses/by/4.0/), which permits use, duplication, adaptation, distribution and reproduction in any medium or format, as long as you give appropriate credit to the original author(s) and the source, provide a link to the Creative Commons license and indicate if changes were made.

The original article has been corrected.

Open Access: This article is distributed under the terms of the Creative Commons Attribution 4.0 International License (http://creativecommons.org/licenses/by/4.0/), which permits unrestricted use, distribution, and reproduction in any medium, provided you give appropriate credit to the original author(s) and the source, provide a link to the Creative Commons license, and indicate if changes were made.

The online version of the original article can be found at

https://doi.org/10.1007/s12274-017-1922-7

Address correspondence to g.r.nash@exeter.ac.uk 